\title{
Ciaran Ross, Aux frontières du vide. Beckett: une écriture sans mémoire ni désir
}

\section{Emanuele Kanceff}

\section{Q OpenEdition}

1 Journals

\section{Edizione digitale}

URL: https://journals.openedition.org/studifrancesi/26838

DOI: $10.4000 /$ studifrancesi.26838

ISSN: 2427-5856

\section{Editore}

Rosenberg \& Sellier

\section{Edizione cartacea}

Data di pubblicazione: 1 avril 2007

Paginazione: 214-215

ISSN: 0039-2944

\section{Notizia bibliografica digitale}

Emanuele Kanceff, «Ciaran Ross, Aux frontières du vide. Beckett: une écriture sans mémoire ni désir», Studi Francesi [Online], 151 (LI | I) | 2007, online dal 30 novembre 2015, consultato il 23 novembre 2021. URL: http://journals.openedition.org/studifrancesi/26838 ; DOI: https://doi.org/10.4000/ studifrancesi.26838

Questo documento è stato generato automaticamente il 23 novembre 2021.

\section{(c)}

Studi Francesi è distribuita con Licenza Creative Commons Attribuzione - Non commerciale - Non opere derivate 4.0 Internazionale. 


\title{
Ciaran Ross, Aux frontières du vide. Beckett: une écriture sans mémoire ni désir
}

\author{
Emanuele Kanceff
}

\section{NOTIZIA}

CIARAN ROSS, Aux frontières du vide. Beckett: une écriture sans mémoire ni désir, Amsterdam, Rodopi, 2004, pp. 305 (Coll. "Faux Titre”, 249).

1 All'origine del percorso critico di Ross sta un simbolo un po' scontato, la sedia nella stanza vuota, che si ricollega alla visione che lo scrittore ebbe nel 1946, a Dublino, nella camera della madre inferma. Questa sconvolgente visione che determina l'opera futura si ricollega a quanto scriveva Kafka sulla necessità di "compiere il negativo, poiché il positivo è già fatto", e si esprime nell' "exploiter le négatif plutôt que le refouler et ainsi faire jouer le vide et l'obscurité en faveur de l'imagination». La lettura di Ross si sviluppa sulla scia del "vide salutaire" che informò la scrittura dell'irlandese, piombato con le sue massime opere nell'abisso del nulla per farne una vera e propria arte, una prassi, una poetica. Ma l'autore vuole in effetti rimettere in discussione il concetto di arte negativa, che in realtà è arte del negativo, nella grande tradizione melanconica della letteratura notturna e abissale, che conta precursori celebri e grandi praticanti. Non senza un certo atteggiamento provocatorio, Beckett ci propone un vuoto necessario che vuol essere la condizione imprescindibile di qualunque creazione letteraria. La scrittura cui egli aspira è del tutto intransitiva e impersonale, senza oggetto, senza origine, senza desiderio, senza memoria, senza storia, scrittura che, secondo una concezione del pensiero "esterno" di Foucault, si estranea da ogni soggettività come per farne emergere dall'esterno i limiti, enunciarne la fine, farne brillare la dispersione e non coglierne in eredità che l'invincibile assenza. 
2 Dalla scena praticamente nuda al ripensamento del negativo, sulla traccia di maestri illustri, si snocciola la prima parte del libro che studia le componenti della poetica del vuoto. La seconda parte ne studia la genealogia, da Godot a L'Innommable, mentre le successive vedono il vuoto messo in scena, il pensiero senza pensante e il terrore senza nome. La Conclusione non può essere che vuota di conclusione, un invito a proseguire la discussione e nello stesso tempo un riconoscimento del potere scaramantico di un libro che è un modo di liberarsi dalle teorie critiche, di anelare alla solitudine di una lettura solitaria. 